Research Article

\title{
The Relationships between Optimism, Happiness and Religious Coping
}

\author{
Sezai Korkmaz ${ }^{1}$
}

Kahramanmaras Sutcu Imam University

${ }^{1}$ Ph.D, Asst. Prof., Kahramanmaras Sutcu Imam University, Faculty of Theology, Department of Psychology of Religion. Kahramanmaras/Turkey. E-mail: kzsezai@gmail.com

Corresponding author:

Sezai Korkmaz

E-mail:

kzsezai@gmail.com

eISSN: 2458-9675

Received: 07.06.2021

Revision: 23.09.2021

Accepted: 09.10.2021

(C) Copyright 2021

by Author(s)

\begin{abstract}
This study aimed to examine the relationship between optimism, happiness and religious coping depending on Carver and Scheier's expectancy-value theory which indicate the basis of optimism and pessimism is confident and doubt. In the current study, participants of the study consist of 323 volunteer Turkish Muslims. $67.7 \%(\mathrm{~N}=219)$ of the sample consisted of female and $32.2 \%(\mathrm{~N}=104)$ of the sample consisted of male. The age range of the participants ranged between 17 and 59 years with mean age of 30.64. In this study The Life Orientation Test (LOT), The Oxford Happiness Questionnaire short form-OHQ-SF and Religious Coping Scale (Brief RCOPE) scales were used. Data was collected through Google documents on the Internet. The data collection sample was not specifically selected and the data were obtained randomly. Findings of correlations showed significant relationships between positive religious coping and optimism, and positive religious coping and happiness. There was negatively a significant relationship between negative religious coping and happiness. The results of the regression weights demonstrated that positive and negative religious coping predicted optimism and happiness. Finally, optimism partially mediated the relationship between positive religious coping and happiness.
\end{abstract}

Keywords:

Optimism, Happiness, Coping, Religious Coping, Religion

\section{İyimserlik, Mutluluk ve Dini Başa Çıkma Arasındaki İlişkiler}

Öz

Bu çalışmanın amacı, Carver ve Scheier'in ortaya atmış olduğu iyimserlik ve kötüimserliğin temelinin güven ve şüphe olduğu ifade eden değer beklentileri teorisine dayalı olarak iyimserlik, mutluluk ve dini başa çıkma arasındaki ilişkileri incelemektir. Bu çalışmanın katılımcıları 323 (yaş ortalamaları 30.64) Türk-Müslüman gönülllïden oluşmaktadır. Örneklemin \%67,7’si ( $N=219)$ kadınlardan, \%32,2'si ( $\mathrm{N}=104)$ erkeklerden meydana gelmektedir. Katılımcılar 17-59 yaşları arasında olup, çalışmanın yaş ortalaması 30,64'tür. Bu çalışmada veriler Yaşam Yönelim Testi, Oxford Mutluluk Ölçeği Kısa Formu ve Dini Başaçıkma Ölçeğiyle toplanmıştır. Veriler internet üzerinden Google Dokümanlar aracılığıyla elde edilmiştir. Katılımcıların belirlenmesi, tesadüfi örnekleme yöntemine dayanmaktadır. Korelasyon bulguları göstermiştir ki olumlu dini başa çıkma ve iyimserlik arasında ve olumlu dini başa çıma ile mutluluk arasında pozitif ve anlamlı ilişki vardır. Olumsuz dini başa çıkma ile mutluluk arasında ise negatif yönde anlamlı ilişki bulunmaktadır. Regresyon ilişkilerine göre olumlu ve olumsuz dini başa çıkma iyimserlik ve mutluluğu yordamaktadır. Son olarak iyimserlik, olumlu dini başa çıkma ile mutluluk arasındaki ilişkide kısmi aracılık yapmaktadır. Anahtar Kelimeler:

İyimserlik, Mutluluk, Başa Çıkma, Dini Başa Çıkma, Din

Citation: Korkmaz, S. (2021). The Relationships between optimism, happiness and religious coping. Spiritual Psychology and Counseling, 6(3), 49-62. https://dx.doi.org/10.37898/spc.2021.6.3.142 
People use coping strategies to avoid chaos from life. At the core of the concept of coping is the assumption of actively surviving and responding to difficult situations (Pearlin \& Schooler, 1978). They reveal different coping styles depending on their feelings and thoughts. Basically, individuals develop positive coping and negative coping strategies (Schwartz, 1986) in order to solve problems in daily life. Pargament et al. (1998) also introduce the concept of religious coping, depending on the concept of coping. The religious coping is divided into positive religious coping and negative religious coping. When the religious coping is evaluated, it is revealed that individuals behave differently according to life stressors. The person's use of negative and positive religious coping also affects well-being and mental health. As in positive coping, people who use positive religious coping have a more positive approach to life. And it uses religious elements in a more positive way. People who use negative religious coping, on the other hand, evaluate religious phenomena more negatively (Pargament, Smith, Koenig, \& Perez, 1998). In this study, the assumption that happiness and optimism changed according to religious coping styles was prioritized.

Seligman pioneered positive psychology that expresses people's well-being, happiness, optimism, forgiveness, humility, spirituality (religiosity) and gratitude in contrast to the disease-based approach of mainstream psychology (Seligman, 2006, 2013). In 1998, Seligman revealed in his book Learned Optimism that there are many types of research about optimism and pessimism. Learned optimism was also an antithesis to the learned helplessness of mainstream psychology (Fariddanesh \& Rezaei, 2019; Seligman, 2006, 2013; Strümpfer, 2006) of mental illness and mental health, along which waxing and waning in the process of fortigenesis moves individuals in the directions of more or less strength; Seligman and Peterson observed that spirituality (or religiosity) is universal and positive psychologists state that spirituality and religiosity are very important in mental health (Peterson \& Seligman, 2004). In addition, psychologists who work on religiosity benefit a lot from positive psychology (Snyder \& Lopez, 2002). Morover, Pargament, who developed the theory of religious coping, has been involved in many studies on positive psychology (Pargament, 1997).

The definitions of optimism and pessimism focus on people's future expectations. The optimist hopes that good things will happen to him in the future. On the contrary, the pessimist hopes that bad things will happen to him in the future (Carver, Scheier, \& Segerstrom, 2010; Carver \& Scheier, 2014). In psychology, optimism and pessimism are based on the expectancy-value model of motivation. According to the expectancyvalue theory, the basis of optimism and pessimism is confident and doubt in the future. If people are confident in achieving their future goals, they are optimistic. If they doubt and withdraw about their future goals, they are pessimistic (Austin \& Vancouver, 1996; Carver et al., 2010; Carver \& Scheier, 2014; Higgins, 2006; Scheier \& Carver, 1992). 
Happiness is that people have a meaningful life, develop positive emotions towards life and are satisfied or get pleasure out of life (e.g. by building hope and optimism or by savoring and mindfulness, etc.) (Seligman, Parks, \& Steen, 2004). Religious coping is often used by people in stressful events or by disenfranchised people in a society. Religious coping is also associated with health and mental health as a result of major critical life events (Pargament, Smith, Koenig, \& Perez, 1998).

People have different views of the world. Some persons take good care of the world. These optimistic people tend to see the positive side of the causes and results of events. On the contrary, some people are pessimistic because they concentrate on the bad side of things (Scheier \& Carver, 1985) defined in terms of generalized outcome expectancies. Two preliminary studies assessed the scale's psychometric properties and its relationships with several other instruments. The scale was then used in a longitudinal study of symptom reporting among a group of undergraduates. Specifically, respondents were asked to complete three questionnaires 4 weeks before the end of a semester. Included in the questionnaire battery was the measure of optimism, a measure of private self-consciousness, and a 39-item physical symptom checklist. Subjects completed the same set of questionnaires again on the last day of class. Consistent with predictions, subjects who initially reported being highly optimistic were subsequently less likely to report being bothered by symptoms (even after correcting for initial symptomreport levels. Researches show that personality dimensions of optimism-pessimism effect psychological well-being, mental health and happiness outcomes (Carver et al., 1993; Scheier \& Carver, 1992; Warren, Van Eck, Townley, \& Kloos, 2015). In terms of positive psychology, when people face troubles and adversity, optimists cope more effectively than pessimists. Coping and religious coping also affect psychological outcomes through optimism. In addition, the findings of meta-analytic study indicate that the relationship between optimism and coping is the strong (Carver et al., 1993; Nes \& Segerstrom, 2006; Pargament \& Raiya, 1980; Warren et al., 2015). In the context of this literature, happiness may also be associated with coping and optimism when evaluated in mental health or well-being. Some studies detect that positive religious coping is significantly associated with happiness (Hebert, Zdaniuk, Schulz, \& Scheier, 2009; Lewis, Maltby, \& Day, 2005).

Some previous studies have addressed the relationship between coping and optimism. In addition, some studies on religiosity have addressed the relationship between religiosity and happiness, or religious coping and optimism (e.g. Lewis et al., 2005; Scheier \& Carver, 1985; Warren et al., 2015). However, at present no study has investigated the relationship between optimism, happiness, and religious coping. Optimism, which is based on the model of behavioral self-regulation, has led to significant behavioral changes, behavioral consequences and behavioral outputs (Carver \& Scheier, 1982a, 1982b; Scheier \& Carver, 1985). 
Previous studies show that religiosity supports mental health as well as having a positive effect on well-being. The issue of religious coping is in many ways related to variables such as mental health, happiness, and optimism. This situation differs according to how one uses religious coping (Kvande, Klöckner, Moksnes, \& Espnes, 2015; Lewis et al., 2005; Pargament, 1997; Warren et al., 2015). Although the effect of religious coping on mental health and happiness is investigated, its relationship with optimism is little known (Kvande et al., 2015). Therefore, the relationship between religious coping (positive and negative) and optimism (and pessimism) should be examined.

The main problem of this study is to examine the relationships between religious coping, happiness and optimism. The studies of Kvande et al., (2015) and Warren et al., (2015) were effective in the emergence of this problem. Because these two studies revealed that there are various statistical relationships between religious coping, optimism and well-being. In addition, Pargament et al., (1998) stated that religious coping is highly effective on mental health and well-being. It was wondered whether similar results would emerge in the Turkish sample. For this reason in the current study, the relationships between religious coping, optimism and happiness are discussed hypothetically and statistically.

\section{Current Study and Hypotheses}

In the current study, the relationships between optimism/pessimism, happiness and religious coping were investigated depending on the model of Carver and Scheier (1982a, 1982b, 1985). In addition, whether optimists or pessimists have used positive religious coping or negative religious coping was examined. The following hypotheses were tested in the context of previous studies and their relationships with each variable. In the study by Warren et al., (2015) a statistically significant relationship was found between religious coping and optimism. In this study, it was revealed that there is a significant relationship between life satisfaction, including happiness, and religious coping. In the research, there is a positive relationship between positive religious coping with optimism and life satisfaction. There is a negative relationship between negative religious coping with optimism and life satisfaction. Based on these findings following hypotheses were formed: $H_{I}$ : Positive religious coping correlates positively with optimism and happiness and $\mathrm{H}_{2}$ : Negative religious coping correlates negatively with optimism and happiness. As it is known, optimism and happiness are considered as elements of well-being. Pargament (1997) stated that optimism, coping and religious coping are effective on well-being. Carver, Scheier \& Segerstrom (2010) also conducted a study confirming this phenomenon. They revealed the relationship between well-being and optimism/pessimism. In particular, the effect of coping on optimism was mentioned. In this direction, following hypotheses were established: $H_{3}$ : Positive and negative religious coping predict optimism, and $H_{4}$ : 
Positive and negative religious coping predict happiness. In the study of Kvande et al., (2015), it was revealed that optimism mediated the relationship between religious coping and well-being. In this context, " $H_{5}$ : Optimism mediates the relationship between positive religious coping and happiness" and " $H_{6}$ : Optimism mediates the relationship between negative religious coping and happiness" were hypothesized.

\section{Methods}

\section{Participants}

Data was collected through Google documents on the Internet. The data collection sample was not specifically selected and the data were obtained randomly. Participants of the study consist of 323 volunteers Turkish Muslims. According to the data obtained with Personal Information Form; 67.7\% (N=219) of the sample consisted of female and $32.2 \%(\mathrm{~N}=104)$ of the sample consisted of male. The age range of the participants ranged between 17 and 59 years with mean age of $30.64 .76 .5 \%(\mathrm{~N}=247)$ of the participants have spent most of their lives in the city, $7.1 \%(\mathrm{~N}=53)$ have lived in the village and $16.4 \%(\mathrm{~N}=23)$ have lived in the town. In terms of marital status, $56 \%(\mathrm{~N}=181)$ of the sample are single and $44 \%(\mathrm{~N}=142)$ are married. According to the economic situation, the majority of the sample consists of middle-income (\%91).

\section{Measurement Tools}

\section{Personal Information Form}

The Personal Information Form which included demographic variables such as gender, age, marital status, income and place of residence by participants, was created by the researcher.

\section{The Life Orientation Test (LOT)}

Optimism was assessed by the Life Orientation Test (Scheier \& Carver, 1985) defined in terms of generalized outcome expectancies. Two preliminary studies assessed the scale's psychometric properties and its relationships with several other instruments. The scale was then used in a longitudinal study of symptom reporting among a group of undergraduates. Specifically, respondents were asked to complete three questionnaires 4 weeks before the end of a semester. Included in the questionnaire battery was the measure of optimism, a measure of private selfconsciousness, and a 39-item physical symptom checklist. Subjects completed the same set of questionnaires again on the last day of class. Consistent with predictions, subjects who initially reported being highly optimistic were subsequently less likely to report being bothered by symptoms (even after correcting for initial symptomreport levels. The scale was developed by Scheier and Carver (1985) to measure 
optimism and pessimism. The scale consists of 12 items. 4 of 12 items were used as filling material. The scale is a five point Likert type ( $5=$ strongly agree, $4=$ agree, $3=$ neutral, $2=$ disagree, and $1=$ strongly disagree). The Turkish adaptation of LOT was applied by Aydın and Tezer (1991). In their study (Aydın \& Tezer, 1991), the Cronbach's alpha was acceptable $(\alpha=.77)$. In this study, Cronbach's coefficient $(\alpha)$ was acceptable $(\alpha=.726)$.

\section{The Oxford Happiness Questionnaire short form-OHQ-SF}

Happiness was assessed by the Oxford Happiness Questionnaire short formOHQ-SF (Hills \& Argyle, 2002)the Oxford Happiness Questionnaire (OHQ. The scale was developed by Hills and Argyle (2002) to measure happiness. The scale consists of 8 items. The scale is a five point Likert type $(5=$ strongly agree, $4=$ agree, $3=$ neutral, $2=$ disagree, and 1=strongly disagree). The Turkish adaptation of OHQSF was applied by Doğan and Çötok. In their study (Doğan \& Çötok, 2011), the Cronbach's alpha was acceptable $(\alpha=.85)$. Doğan and Çötok (2011) fourth item (I don't think I look attractive) of The Turkish adaptation of OHQ-SF was extracted from the scale because of item total correlation value (.17) was lower than .30. In this study, Cronbach's coefficient $(\alpha)$ was acceptable $(\alpha=.809)$.

\section{Religious Coping Scale (Brief RCOPE)}

Religious coping was assessed by the Positive and Negative Natterns of Religious Coping Scale (Brief RCOPE) (Pargament, Smith, Koenig, \& Perez, 1998). The scale was developed by Pargament, Smith, Koenig, and Perez (1998) to measure religious coping. Positive and Negative Natterns of Religious Coping Scale (Brief RCOPE) consist positive religious coping and negative religious coping. The scale consists of 10 items and 2 subscales. The scale is a four point Likert type ( 0 "not at all" to 3 "a great deal"). The Turkish adaptation of Positive and Negative Natterns of Religious Coping Scale (Brief RCOPE) was applied by Ekşi and Sayın (2016). In their study (Ekşi \& Sayın, 2016), the Cronbach's alpha (item totals of the whole scale) was acceptable $(\alpha=.69)$. The Cronbach's alpha of positive religious coping was acceptable $(\alpha=.64)$. The Cronbach's alpha of negative religious coping was acceptable $(\alpha=.63)$. In this study, Cronbach's (item totals of the whole scale) coefficient $(\alpha)$ was acceptable $(\alpha=.909)$. In the current study, the Cronbach's alphas of positive religious coping and negative religious coping were acceptable (.933, and .905 respectively).

\section{Data Collection}

Data on the relationships between religious coping, optimism and happiness were collected through a questionnaire. Survey data was obtained via the internet and Google Docs. Various social media sites and communication tools have been used. 
Participants were included in the survey as volunteers. A consent form was presented to the participants before the survey was conducted. Necessary information was given to the participants in line with the consent form, and the person who filled out the questionnaire accordingly approved the consent form. Considering these principles, the survey application was carried out between 08 July 2019 and 01 August 2019. Ethics committee approval was not required as the survey was conducted with adults. This study complied with ethical standards.

\section{Data Analysis}

After the survey was done, the data were coded via SPSS. Missing values were determined in the surveys and necessary corrections were made. In this study, Structural Equation Modelling (SEM) and descriptive analysis were used. Analysis of Moment Structure 21 (AMOS) and Statistical Package for Social Sciences (SPSS), package version 18 were used to analyze the data. Regression and mediator variable were analyzed with the help of AMOS. Correlations were analyzed with both SPSS and AMOS and the same findings were obtained.

\section{Results}

The main purpose of this study is to examine the relationships between optimism, happiness and religious coping. Therefore, in regard to the hypotheses of the current research, firstly, the correlations between the variables were analyzed. Secondly, the way in which religious coping predicts optimism and happiness were examined. Finally, the mediations of optimism on the relationship between positive/negative religious coping and happiness were investigated. The correlations between the variables were presented in Table 1 below.

Table 1.

Correlations between variables

\begin{tabular}{lccccccccc}
\hline Variables & Mean & SD & Skewness & Kurtosis & $\alpha$ & 1 & 2 & 3 & 4 \\
\hline (1) PRC & 3,17 &, 804 & $-1,293$ & 1,082 & .933 & 1 & & & \\
(2) NRC & 2,49 & 1,00 &, 028 & $-1,195$ & .905 & $.409^{* *}$ & 1 & & \\
(3) Optimism & 3,29 &, 819 &,- 513 & -074 & .726 & $.239^{* *}$ & -.063 & 1 & \\
(4) Happiness & 3,27 &, 739 &,- 232 &,- 306 & .809 & $.276^{* *}$ & $-.174^{* *}$ & $.605^{* *}$ & 1 \\
\hline
\end{tabular}

$\mathrm{n}=323 * * \mathrm{p}<0.01$

The correlation coefficients between the variables observed (positive/negative religious coping, optimism, happiness) before regressions were analyzed. Correlation was investigated according to both the structural equation model and Pearson correlation coefficients. The results of both (SEM and Pearson) analyses were presented in Table 1. The findings of the study showed that there was a relationship between positive religious coping and optimism. The correlation between positive religious coping and optimism was a significant positive relationship $(r=.239, p$ 
$<0.01)$. In other words, the increasing use of positive religious coping promoted optimism. When the correlation was considered, it was possible to say the opposite. The results indicated that the highest correlation had appeared between positive religious coping and happiness $(r=.276, p<0.01)$. There was a significant positive relationship between positive religious coping and happiness. Therefore, it could be stated that religious coping would contribute to happiness (Table 1).

According to the correlation results in Table 1, a relationship was not found between negative religious coping and optimism $(r=-.063, p>0.01)$. The results of the last correlation analysis in this study indicated that correlation was observed between negative religious coping and happiness $(r=-.174, p<0.01)$. There was a significant negative relationship between negative religious coping and happiness. Thus, increased use of negative religious coping would lead to a decrease in happiness (Table 1). In the current study, after correlation analysis, regression analysis was examined. Both regression analysis and mediation analysis could be performed in a study (Baron \& Kenny, 1986). It might also be necessary to resort to regression analysis as a prerequisite for mediation. Table 2 below was presented the regression weights.

Table 2.

Regression weights

\begin{tabular}{lcccc}
\hline Path & Standardized coefficient $(\beta)$ & Standard error & $t$ value & $p$ \\
\hline Positive religious coping ---> optimism & .318 & .059 & 5.450 & $* * *$ \\
Positive religious coping ---> happiness & .276 & .051 & 7.517 & $* * *$ \\
Negative religious coping ---> optimism & -.193 & .048 & -3.308 & $* * *$ \\
Negative religious coping ---> happiness & -.345 & .041 & -6.211 & $* * *$ \\
\hline$* * * p<0.001$ & & &
\end{tabular}

Findings of structural model analysis indicated that positive religious coping has affected positively on optimism $(\beta=.318, \mathrm{p}<.001)$ and happiness $(\beta=.276, \mathrm{p}<$ $.001)$. The results also showed that negative religious coping negatively affected on optimism $(\beta=-.193, \mathrm{p}<.001)$ and happiness $(\beta=-.345, \mathrm{p}<.001)$. According to $\Delta \mathrm{R}^{2}$ values positive religious coping explained $32 \%$ of the variance of optimism and $28 \%$ of the variance of happiness. Furthermore, according to $\Delta \mathrm{R}^{2}$ values negative religious coping explained $19 \%$ of the variance of optimism and $35 \%$ of the variance of happiness (see Table 2).

In this study, after the regression analysis, the model of mediator variable was tested (see Figure 1). In an attempt to investigate the mediating roles of optimism in the links between positive/negative religious coping, and happiness path analysis was used to assess the statistical significance of indirect effects (Fox, 1980). According to the model in Figure 1, there have to be some conditions for the mediating variable role. The path coefficients from positive religious coping to optimism $(\beta=.239, \mathrm{p}<$ $.001)$ and from optimism to happiness $(\beta=.572, \mathrm{p}<.001)$ were statistically significant. 
Table 3.

Bootstrap Analysis

\begin{tabular}{|c|c|c|c|}
\hline \multirow{2}{*}{ Prc $>$ Happiness } & \multirow{2}{*}{$* \mathrm{p}=.000$} & \multicolumn{2}{|c|}{ Bootstrap } \\
\hline & & Lower & Upper \\
\hline Direct Effects & $139 *$ &, 029 &, 227 \\
\hline Indirect Effects &, $137 *$ &, 063 & , 194 \\
\hline Total Effects &, $276^{*}$ &, 134 &, 371 \\
\hline
\end{tabular}

These conditions respectively; in the total effects, the path coefficients from positive religious coping $(\beta=.276, \mathrm{p}<.001)$ to happiness was statistically significant. Results of direct model (Figure 1 and Table 3 ) revealed that the path coefficients from positive religious coping to happiness $(\beta=.139, \mathrm{p}<.001)$ was reduced, but still significant. The standardized indirect effect of positive religious coping on happiness was ,137. As seen in Figure 1 and Table 3, the direct effect of positive religious coping on happiness was ,139. It was written as , 14 rounded up in the Figure 1. The model fits of the mediation analysis were $x^{2} / \mathrm{df}=4,31 ; \mathrm{CFI}=, 912 ; \mathrm{TLI}=, 894 ; \mathrm{GFI}=, 901$; $\mathrm{SRMR}=, 053 ; \mathrm{RMSEA}=, 065$. These model fit values are at an acceptable level (Kline, 2011). Therefore, optimism appeared as a partial mediator in the relationship between positive religious coping and happiness (see Figure 1).

Figure 1.

Mediation Model-1

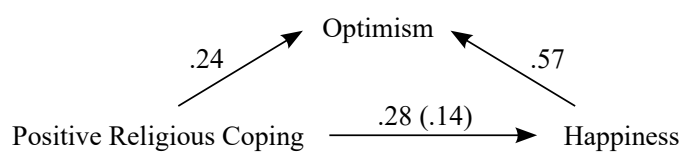

\section{Discussion}

The main purpose of the current study was to analyze the relationship between optimism, happiness, and religious coping. This research was forecasted to lend and close the gap that continues in the present literature concerning the essential variables of the research of cultures outside the Judeo-Christian tradition, notably within Muslim samples. Moreover, the current study was considered to be important as the relationship between optimism, happiness, and religious coping was tackled within the Muslim sample for the first time. Primarily, the theoretical background was given in this research. Then, correlations, regression weights, and mediator analysis between variables were examined with the data obtained from the sample.

The correlation matrix findings of the current study showed that there were statistically and significant correlations between positive religious coping, optimism and happiness (see Table 1). Positive religious coping were positively correlated with optimism and happiness. Accordingly, results indicated that " $\mathrm{H}_{1}$ positive religious coping correlate positively with optimism and happiness" hypothesis was confirmed. In addition, there was no statistically significant relationship between negative religious coping and 
optimism. But, negative religious coping was negatively correlated with happiness. These results showed that the $\mathrm{H}_{2}$ hypothesis that "negative correlation between negative religious coping and optimism" was not confirmed, while the negative relationship between negative religious coping and happiness was confirmed.

Results of the current study indicated that positive religious coping was positively associated with optimism and happiness. For example, the correlation findings of this study in the context of the relationship between positive religious coping and optimism were consistent with a study examined in 533 residents of South Carolina with psychiatric disabilities. In the study conducted in Southern Carolina, it was found that there was a significant positive relationship between positive religious coping and optimism and there was also a significant negative relationship between negative religious coping and optimism (Warren et al., 2015). But, the correlation findings of the current study in the context of the relationship between negative religious coping and optimism were not consistent with research of Warren et al., (2015). Because the findings of this study showed that there was no statistically significant relationship between negative religious coping and optimism.

According to the findings of this study, there was statistically significant relationship between religious coping and happiness. A positive correlation was found between positive religious coping and happiness, while a negative correlation was found between negative religious coping and happiness. These results of the current study were consistent with and similar to other studies. For instance, in studies conducted in different countries on Muslim and non-Muslim sample, it was found that there was a positive relationship between positive religious coping and happiness, and a negative relationship between negative religious coping and happiness (Abarghouei, Sorbi, Abarghouei, \& Bidaki, 2016; Fallah, Mangoli, \& Zare, 2012; Lewis et al., 2005; Mohammad, Akbar, \& Hossein, 2012).

In the path analysis, positive and negative religious coping predicted and affected optimism and happiness. These findings supported the $\mathrm{H}_{3-4}$ research hypotheses that positive and negative religious coping predicts optimism and positive and negative religious coping predicts happiness (see Table 2). The results of positive and negative religious coping regression weights for optimism in the current study showed that were consistent with the findings of another study. In a study, positive religious coping and negative religious coping predicted optimism. Positive religious coping had a positive effect on optimism while negative religious coping had a negative effect on optimism (Warren et al., 2015). The results of positive and negative religious coping regression weights for happiness in the current study also indicated that was consistent with the findings of the other studies (Barrett \& Pargament, 1998; Fallah et al., 2012; Hebert et al., 2009; Lewis et al., 2005; Mohammad et al., 2012; Pargament, 1997; 
Park, Holt, Le, Christie, \& Williams, 2018; Warren et al., 2015). For instance, The Study of Abarghouei, Sorbi, Abarghouei, and Bidaki (2016) examined that religious coping affected happiness. According to the results of these researches, positive and negative religious coping predicted happiness as in the current study. Therefore, it could be said that this study supported previous studies.

Optimism partially mediated the relationship between positive religious coping and happiness. The finding of the current study from the mediation test supported the $\mathrm{H}_{5}$ research hypothesis that optimism mediates the relationship between positive religious coping and happiness (see Figure 1). But, optimism did not mediate the relationship between negative religious coping and happiness. The result of this research from mediation analysis did not support the $\mathrm{H}_{6}$ research hypothesis that optimism mediates the relationship between negative religious coping and happiness.

The findings of current study were consistent with the research of Warren et al., (2015) which stated that optimism mediates the relationship between positive religious coping and psychological distress and life satisfaction. In addition, the study of Warren et al., (2015) showed that optimism mediated the relationship between negative religious coping and psychological distress and life satisfaction. There could not be detected that previously was conducted a study that indicated optimism mediated the relationship between positive religious coping and happiness.

Considering the possible causes of the findings, the correlation between positive religious coping with optimism and happiness could be evaluated in the context of positive psychology. In the positive psychology approach, there was an assumption that positive variables could be related to each other (Seligman, 2013). In this study, the relationship between positive religious coping, optimism and happiness could be evaluated in this context. When assessed in the context of the relationship between mental health and religiosity, it was seen that religiosity had a positive effect on mental health (Dezutter, Soenens, \& Hutsebaut, 2006). In addition, religiosity predicted variables such as well-being and psychological resilience, which was one of the positive indicators of the relationship between mental health and religiosity (Aghababaei et al., 2016). In this respect, it could be said that positive religious coping predicted happiness and optimism positively. Moreover, it could be appraised in this way that optimism partially mediated the relationship between positive religious coping and happiness, and that it did not mediate the relationship between negative religious coping and happiness.

\section{Conclusion}

The results of current study showed that there were positive relationships between positive religious coping and optimism and happiness as the correlation coefficients. In addition, a negative correlation was found between negative religious coping and happiness. However, there was no statistically significant relationship between 
negative religious coping and optimism. According to the regression weights, positive and negative religious coping predicted both optimism and happiness. Moreover, optimism partially mediated the relationship between positive religious coping and happiness. Nevertheless, optimism did not mediate the relationship between negative religious coping and happiness. It could be recommended for future studies to include the religiousness variable in the model of the study. In addition, it might be beneficial to add variables such as depression and anxiety. Because when looking at the literature, the relationships between religious coping and both positive (such as well-being etc.) and negative (such as anxiety etc.) variables were also examined.

\section{Compliance with Ethical Standards}

Conflict of Interest Author declares that there is no potential conflict of interest relevant to this study

Funding The author has received no financial support.

Ethical Approval This study was conducted in accordance with the ethical standards of the institution/university or national/public research committee and with the 1964 Declaration of Helsinki.

\section{References}

Abarghouei, M., Sorbi, M. H., Abarghouei, M. R., \& Bidaki, R. (2016). The relationship between religious coping strategies and happiness with meaning in life in blind people. Global Journal of Health Science, 9(1), 130. https://doi.org/10.5539/gjhs.v9n1p130

Aghababaei, N., Sohrabi, F., Eskandari, H., Borjali, A., Farrokhi, N., \& Chen, Z. J. (2016). Predicting subjective well-being by religious and scientific attitudes with hope, purpose in life, and death anxiety as mediators. Personality and Individual Differences, 90, 93-98. https://doi.org/10.1016/j.paid.2015.10.046

Austin, J. T., \& Vancouver, J. B. (1996). Goal constructs in psychology: Structure, process, and content. Psychological Bulletin, 120(3), 338-375. https://doi.org/10.1037/0033-2909.120.3.338

Aydın, G., \& Tezer, E. (1991). İyimserlik, sağılı sorunları ve akademik başarı ilişkisi. Türk Psikoloji Dergisi, 7(26), 2-9.

Baron, R. M., \& Kenny, D. A. (1986). The moderator-mediator variable distinction in social psychological research: conceptual, strategic, and statistical considerations. Journal of Personality and Social Psychology, 51(6), 1173-1182. https://doi.org/10.1037//00223514.51.6.1173

Barrett, J. L., \& Pargament, K. I. (1998). The psychology of religion and coping: theory research practice. Review of Religious Research, 40(1), 89. https://doi.org/10.2307/3512468

Carver, C. S., Pozo, C., Harris, S. D., Noriega, V., Scheier, M. F., Robinson, D. S., ... Clark, K. C. (1993). How coping mediates the effect of optimism on distress: a study of women with early stage breast cancer. Journal of Personality and Social Psychology, 65(2), 375-390. https://doi.org/10.1037//0022-3514.65.2.375 
Carver, Charles S., \& Scheier, M. F. (1982a). Control theory: A useful conceptual framework for personality-social, clinical, and health psychology. Psychological Bulletin, 92(1), 111135. https://doi.org/10.1037/0033-2909.92.1.111

Carver, Charles S., \& Scheier, M. F. (1982b). Outcome expectancy, locus of attribution for expectancy, and self-directed attention as determinants of evaluations and performance. Journal of Experimental Social Psychology, 18(2), 184-200. https://doi.org/10.1016/00221031(82)90049-X

Carver, Charles S., Scheier, M. F., \& Segerstrom, S. C. (2010). Optimism. Clinical psychology review, 30(7), 879. https://doi.org/10.1016/J.CPR.2010.01.006

Carver, Charles S, \& Scheier, M. F. (2014). Dispositional optimism. Trends in Cognitive Sciences, 18(6), 293-299. https://doi.org/10.1016/j.tics.2014.02.003

Dezutter, J., Soenens, B., \& Hutsebaut, D. (2006). Religiosity and mental health: A further exploration of the relative importance of religious behaviors vs. religious attitudes. Personality and Individual Differences, 40(4), 807-818. https://doi.org/10.1016/j.paid.2005.08.014

Doğan, T., \& Çötok, N. A. (2011). Oxford mutluluk ölçeği kısa formunun türkçe uyarlaması: Geçerlik ve güvenirlik çalışması. Türk Psikolojik Danışma ve Rehberlik Dergisi, 4(36), 165-172.

Ekşi, H., \& Sayın, M. (2016). The adaptation of Religious Coping Scale into Turkish language: A study of bilingual equivalance, validity and reliability. In AGP Humanities and Social Sciences Conference. Berlin: BAU International Berlin University.

Fallah, M. H., Mangoli, A., \& Zare, F. (2012). Examining the effect of teaching religious coping style on happiness of parents with exceptional children. Toloo-E-Behdasht, 11(235), 75-82.

Fariddanesh, M., \& Rezaei, A. M. (2019). Predicting the happiness of adolescents based on coping styles and religious attitudes. Journal of Religion and Health, 58(2), 537-553. https://doi.org/10.1007/s10943-017-0497-7

Fox, J. (1980). Effect analysis in structural equation models. Sociological Methods \& Research, 9(1), 3-28. https://doi.org/10.1177/004912418000900101

Hebert, R., Zdaniuk, B., Schulz, R., \& Scheier, M. (2009). Positive and negative religious coping and well-being in women with breast cancer. Journal of Palliative Medicine, 12(6), 537-545. https://doi.org/10.1089/jpm.2008.0250

Higgins, E. T. (2006). Value from hedonic experience and engagement. Psychological Review, 113(3), 439-460. https://doi.org/10.1037/0033-295X.113.3.439

Hills, P., \& Argyle, M. (2002). The Oxford Happiness Questionnaire: A compact scale for the measurement of psychological well-being. Personality and Individual Differences, 33(7), 1073-1082. https://doi.org/10.1016/S0191-8869(01)00213-6

Kline, R. B. (2011). Principles and Practice of Structural Equation Modeling. New York: Guilford Publications.

Kvande, M. N., Klöckner, C. A., Moksnes, U. K., \& Espnes, G. A. (2015). Do optimism and pessimism mediate the relationship between religious coping and existential well-being? Examining mechanisms in a Norwegian population sample. International Journal for the Psychology of Religion, 25(2), 130-151. https://doi.org/10.1080/10508619.2014.892350

Lewis, C. A., Maltby, J., \& Day, L. (2005). Religious orientation, religious coping and happiness among UK adults. Personality and Individual Differences, 38(5), 1193-1202. https://doi.org/10.1016/J.PAID.2004.08.002 
Mohammad, R., Akbar, S. A., \& Hossein, B. M. (2012). The relationship between coping patterns, mental health and happiness. Development Psychology (Journal of Iranian Psychologists), 8(32), 363-371.

Nes, L. S., \& Segerstrom, S. C. (2006). Dispositional optimism and coping: A meta-analytic review. Personality and Social Psychology Review, 10(3), 235-251.https://doi.org/10.1207/ s15327957pspr1003_3

Pargament, K. I. (1997). The psychology of religion and coping : Theory, research, practice. New York, NY: Guilford Press.

Pargament, K. I., \& Raiya, H. A. (1980). A decade of research on the psychology of religion and coping: Things we assumed and lessons we learned. Psyke \& Logos, 28(2), 25.

Pargament, K. I., Smith, B. W., Koenig, H. G., \& Perez, L. (1998). Patterns of Positive and Negative Religious Coping with Major Life Stressors. Journal for the Scientific Study of Religion, 37(4), 710. https://doi.org/10.2307/1388152

Park, C. L., Holt, C. L., Le, D., Christie, J., \& Williams, B. R. (2018). Positive and negative religious coping styles as prospective predictors of well-being in African Americans. Psychology of Religion and Spirituality, 10(4), 318-326. https://doi.org/10.1037/rel0000124

Pearlin, L. I., \& Schooler, C. (1978). The structure of coping. Journal of Health and Social Behavior, 19(1), 2-21. https://doi.org/10.2307/2136319

Peterson, C., \& Seligman, M. (2004). Character Strengths and Virtues: A Handbook and Classification. New York: Oxford University Press.

Scheier, M. F., \& Carver, C. S. (1985). Optimism, coping, and health: assessment and implications of generalized outcome expectancies. Health psychology : Official Journal of the Division of Health Psychology, American Psychological Association, 4(3), 219-247.

Scheier, Michael F., \& Carver, C. S. (1992). Effects of optimism on psychological and physical well-being: Theoretical overview and empirical update. Cognitive Therapy and Research, 16(2), 201-228. https://doi.org/10.1007/BF01173489

Schwartz, R. M. (1986). The internal dialogue: On the asymmetry between positive and negative coping thoughts. Cognitive Therapy and Research 1986 10:6, 10(6), 591-605. https://doi.org/10.1007/BF01173748

Seligman, M. (2006). Learned optimism : how to change your mind and your life. New York, NY: Vintage Books.

Seligman, M. (2013). Authentic happiness : using the new positive psychology to realize your potential for lasting fulfillment. New York, NY: Atria.

Seligman, M., Parks, A. C., \& Steen, T. (2004). A balanced psychology and a full life. Philosophical transactions of the Royal Society of London. Series B, Biological sciences, 359(1449), 1379-1381. https://doi.org/10.1098/rstb.2004.1513

Snyder, C. R., \& Lopez, S. J. (2002). The future of positive psychology. New York: Oxford University Press.

Strümpfer, D. J. W. (2006). The strengths perspective: Fortigenesis in adult life. Social Indicators Research. https://doi.org/10.1007/s11205-005-5551-2

Warren, P., Van Eck, K., Townley, G., \& Kloos, B. (2015). Relationships among religious coping, optimism, and outcomes for persons with psychiatric disabilities. Psychology of Religion and Spirituality, 7(2), 91-99. https://doi.org/10.1037/a0038346 